\title{
A NEW MODEL FOR MEASURING INSTRUCTIONAL EFFECTIVENESS AND STUDENT LEARNING IN THE CLASSROOM
}

\author{
Carl M. Rebman, Jr, University of San Diego,carlr@sandiego.edu \\ Deborah Kelly, University of San Diego,dkelly@sandiego.edu \\ Frank Alaba Ogedengbe, Auchi Polytechnic,franklaba@yahoo.com
}

\begin{abstract}
The issue of instructional effectiveness has been a concern that has been debated for many years. While there have been many discussions over which method is best used to determine how instructional effectiveness is calculated, one main area method used by administrators is either the student evaluation of teaching (SET) or student evaluation of faculty (SEF). This paper proposes a new model where administrators consider other additional metrics as a means of determining instructor effectiveness and student learning. Two specific metrics include using a pre/post Computing Self-Efficacy survey evaluation and a specific task item Self-Efficacy survey. These metrics were applied to an introductory information system course. The results indicate that by utilizing both metrics faculty and administrators can find a better method for determining student engagement and instructional effectiveness in the classroom than the tradition student evaluation of teaching method.
\end{abstract}

Keywords: Student Evaluation of Teaching, Instruction Effectiveness, Student Learning, Self-Efficacy, Certification Testing, Assessment and Information Systems Education

\section{INTRODUCTION}

Education has always been considered to be an important component to economic growth and development. Berdahl, et. al [5], notes that 'the importance of higher education to the nation's future in a global economy becomes increasingly visible.' Brown and Lauder [8] also agree with the Modernizer's belief that 'the upgrading of educational standards is seen as central to the delivery of social justice and economic growth.' As such it is not surprising that much attention be focused on seeking to measure student performance and determining causes for success or failure in our current education system.

One such area that draws a large amount of attention is the area of instructor effectiveness particularly as it relates toward student performance. This issue has ranged from individuals calling for teachers to be fired [18] to a more explicit mention by President Obama's education plan where he calls for "teachers to be held accountable for the performance of their students." [30].

Currently one of the main instruments used by administrators for evaluation of instructor effectiveness is the student evaluation of teaching (SET). For example, according to Clayson [12] almost all business schools (99.3\%) use some form of a SET and deans generally place a higher importance on these than either administrative or peer evaluations [13]. This belief was reinforced by Wilson [34] who found that on many campuses, student evaluations are the most important, and in many cases, the only measure of teaching ability. Clayson [12] found a quote by Seldin [31] who reported a California dean as saying, "if I trust one source of data on teaching performance, I trust the students" (pg 15). This is not surprising given that student evaluations have existed for quite some time with the first published article written by a researcher from Purdue University more than 80 years ago (Remers \& Brandenburg [29], 1927, as cited in Kulick [19] and Clayson [12]).

Models other than the SET exist and administrators could seek to consider at least other metric models that assess performance and student self-evaluation of skills. Because of the importance and need for high student performance and teacher effectiveness, this paper researches the use of a pre-course survey to measure student experience and knowledge of course topics to compare to post-course survey results. Instructors can tailor the depth of course discussion and practice assignments to best meet the needs of the students by using the pre-survey results. Seating assignments can pair students of different abilities to help with reinforcement and enhancement of learning. Students will have a preview of the concepts and topics covered in addition to the expectations and requirements to perform well. This preparation can help solicit the student's role as a stakeholder in the learning process. 


\section{Issues in Information Systems \\ Volume 14, Issue 2, pp.298-305, 2013}

This paper proposes a new evaluation model that utilizes computing self-efficacy topics to further assess student engagement and instructor effectiveness. The hypotheses tested whether students would report a higher rating of knowledge and experience with computers and specific task items in Excel using surveys at the beginning and end of the semester. The format of this study is to discuss the concept of teaching effectiveness, the reliability and viability of the SET, describe other methods/metrics that have been used to define and determine instructor effectiveness, discuss a new model for determining instructor effectiveness, and report the results of the new measurements methods.

\section{BACKGROUND}

Boex [6] conducted a vast literature review which found that teaching is a multidimensional process comprising a number of separable dimensions or instructor attributes $([3,10,11,14,22])$. Boex [6] also found a broad consensus within the education literature that recognizes an instructor's overall effectiveness depends on a combination of instructor attributes, such as the clarity of the instructor's lectures, the course's organization, the degree to which the instructor motivates students, and the instructor's success in building an interpersonal rapport with the students. Galliard, et.al [15] also points out that there are other factors such as: a professor depth of knowledge, technical ability, the use of technology in class, and teaching skill that can be just as important. One other interesting item that was found in the research is that students and instructors when surveyed reported similar characteristics, when asked to describe what defines a 'good professor.' For example in a study by Miron [25] where instructors of various ranks were asked to indicate one or more characteristics they related four aspects: scholarship, delivery, advising, and instructor's personal traits. Pholmann [28] conducted an analysis of similar studies where students were asked the same questions. The overall traits reported as essential were a thorough knowledge of subject matter, giving well planned and organized lectures, enthusiasm and interest in teaching, and a student orientation/willingness to assist outside of the classroom.

As one might expect, the research on the student evaluation process is mixed with respect to reliability, validity and potential bias. Wallace and Wallace [33] found that most students were honest while Gomez-Mejia and Balkin [16] found that teaching ratings by students do not reflect true teaching performance due to a popularity contest. Another challenge with student evaluation is the relationship between grades and SET. There have been many studies that have provided results that indicate there is an apparent grade/evaluation association [7, 9, 23]. Two other hypotheses are about leniency and reciprocity. The leniency hypothesis states those students who have lenient grading instructors give better evaluations. The reciprocity hypothesis is the belief that instructors intentionally assign higher grades near the time the student evaluation is performed. While the debate over the validity of these hypotheses continues, it does not appear to change the behavior of both faculty and students who believe such a relationship exists [12].

A recent critique of the current and future direction of colleges and universities suggests that the evaluation questionnaire resembles a customer satisfaction survey [32]. Questions ask if the instructor met the student's needs or how enjoyable the class was rather than how much they learned. In addition, the high percentage of adjunct faculty compared to full-time is having an effect on grading and evaluations. In order to have renewed contracts, adjuncts may ensure a good evaluation by grading more leniently than those who are assured of their next year positions.

Wode and Kesier [35] found some interesting items regarding the validity and reliability of course evaluations in their background report on student course evaluation as part of the Columbia College Chicago Evaluation and Assessment Program. For example, they found that alumni rarely change their opinion of former teachers $[1,11]$ and that when instructors conduct midterm evaluation and have honest discussions with them, it can lead to higher evaluations [26]. One last result they found was that contrary to the 'retaliation' theory, students who do poorly in a class are equally or less likely than those who do well to complete course evaluations [20].

Despite concerns about validity of student evaluations and the challenges of creating an accepted standard definition of 'good' teacher/teaching effectiveness, there is still a desire to find alternative models that provide some indication of student learning and teacher evaluation. For example, Looney [21] reports that different forms of teaching evaluation could take the shape of teacher evaluation focus on individual teaching performance in classrooms (teacher appraisal; teacher peer evaluation and student ratings); the school context (external school inspection and 


\section{Issues in Information Systems \\ Volume 14, Issue 2, pp.298-305, 2013}

internal school self-evaluation) and student outcomes (national or regional student assessments and value-added assessments to measure gains in learning over time). Looney [21] further mentions that many institutions practice a combination of these items and suggests that any attempt at determining teaching effectiveness and competencies be aligned with similar standards for student learning and competences.

\section{PROPOSED EVALUATION MODEL WITH COMPUTING SELF-EFFICACY}

This paper proposes utilizing a model of student self-evaluation along with recording actual performance on assessment instruments as indicators of instructor effectiveness. The start of the model was to create a simple presemester survey that would be presented to students to assess their computer literacy skills. Once the semester had been completed the students would be asked to respond to a post-semester survey. These results would then be compared along with actual scores from class assessment devices such as assignments and examinations in order to determine if student performance and instructional effectiveness could be evaluated. Figure 1 is an illustration of the new model that we propose followed by a description of the process.

This new proposed model seeks to utilize some of the concepts of Albert Bandura self-efficacy and social cognitive theory. Bandura first introduced the concept of self-efficacy when he presented his theory that individuals possess a self-system that enables them to exercise a control over their thoughts, feelings, and actions. It is within this selfsystem that an individual can learn from others and create reference mechanisms that can end with engaging in selfreflection. These self-reflections can lead to self-efficacy beliefs in one's capabilities to organize and execute the courses of action required to manage prospective situations [4].This self-efficacy leads to either a high or low condition where an individual with low self-efficacy tends to believe that things are tougher than they really are and individuals with high self-efficacy have a greater sense of serenity in approaching difficult tasks and activities [27]. Bandura [4] wrote that self-efficacy beliefs are strong determinants and predictors of level of accomplishments.

Perhaps one of the main tenets of instructional effectiveness is the ability to engage student learning with producing strong outcome performance. The self-efficacy component was selected because it was felt that it could be applied to the challenge of determining instructional effectiveness and student learning with successful results. The inclusion of self-efficacy in academia is not a new concept. For example, during the past two decades, self-efficacy has emerged as a highly effective predictor of students' motivation and learning [27].

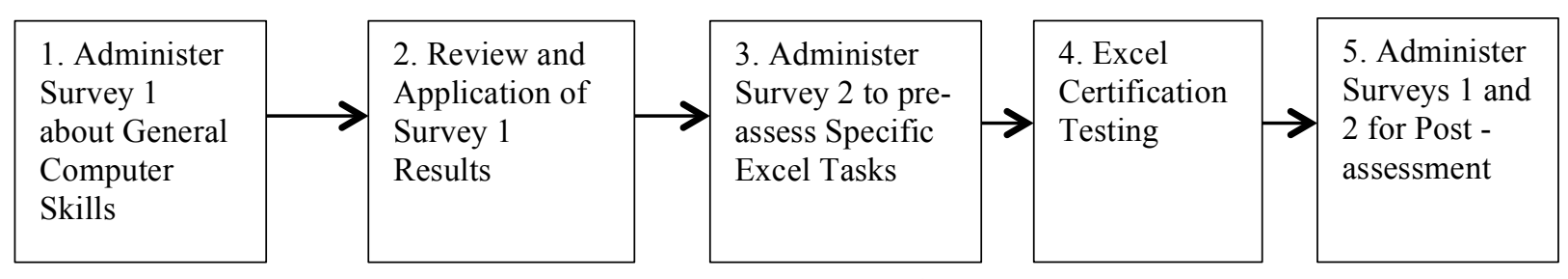

Figure 1. Process of Evaluation

1. The first step of the process is to conduct a survey at the beginning of the semester to determine each student's personal assessment of their experience and knowledge of the overall general concepts of the course. The survey will not only give students a preview of what they can expect in the course but also be a tool to solicit the student's role as a stakeholder in the learning process.

2. The instructor will review the results and have a discussion with the students. Some discussion should be a reinforcement of how all responses should increase as a result of the course. Another benefit of the results is that the instructor can make classroom seating assignments based on each individual's reported score (e.g. placing low scoring individuals next to those who reported a higher rating). Lastly, the results can be integrated into the course by highlighting in lecture and practice those elements where students scored low. An instructor can be more effective in teaching the subject material when they are aware of the specific items that students purport to be familiar with and can concentrate on items that students appear to need more exposure.

3. The instructor will relate during lecture and practice the specific Excel task items that will be assessed in Survey 2. Then Survey 2 will be given. 


\section{Issues in Information Systems \\ Volume 14, Issue 2, pp.298-305, 2013}

4. This model was created to suit a specific course, namely Introduction to Information Systems, where one of the main deliverables is performing well on an Excel test for Microsoft Office Certification (MOS). Once the Excel Certification scores have been revealed to the students and missed concepts are explained then the final step is to administer both surveys again to assess the experience and knowledge learned about general computer skills and specific Excel tasks.

\section{RESEARCH METHODOLOGY}

The course selected was an Introductory to Information Systems Course that covers Excel, Access, and MIS concepts. Students also engaged in two computer-based instructional systems, namely myITlab and GMetrix. The myITlab system is a self-based homework solution system to accompany lecture examples and GMetrix is a computer test preparation solution for the MOS Certification Exam.

Two different types of measurements were performed. The first survey was a general questionnaire to which students were asked to rate their experience with computers, programs, and information system concepts. This survey was administered at the beginning and at the end of the semester and asked students to rank their knowledge and experience of the items from 1- low or little knowledge to 10 - high, very knowledgeable. The survey items were: comfort with computers, Microsoft Office products Word, Excel, Access, and PowerPoint, knowledge of how the web works, knowledge of HTML and creating web pages, and knowledge of computer networks and information systems.

The second survey was created to evaluate the student's confidence with specific task items in Excel. Tables $2 \mathrm{a}$ and $2 \mathrm{~b}$ show the specific tasks in which they ranked their ability to execute the tasks from 1 - no ability to execute this task to 10 - complete ability to execute this task. The students had been informed that these items would make up a majority of the certification test. This survey was provided to the student after 5 weeks of instruction but 2 weeks before the actual exam. A post survey was administered after they had completed the exam and had received their scores.

This paper sought to assess if there was an increase in reported self confidence in using technical concepts and programs that were taught over the semester. Hence the main research questions were: 1. Can the use of pre-course surveys of student experience of planned course topics be used to measure student knowledge of course topics? 2. Can the use of pre-test surveys of student knowledge of specific MS Excel test task items be used to measure student knowledge of specific MS Excel test task items? Statistically, the expectation was a significant mean difference between the pre-semester survey results and the post-semester survey results. The following are two hypotheses that were tested.

$\mathrm{H}_{1}$ : Students will report a higher rating of knowledge and experience with computers, IS concepts, web, and Microsoft Office applications.

$\mathrm{H}_{2:}$ Students would report higher rating of knowledge of specific task items in Excel.

\section{RESULTS AND DISCUSSION}

Ninety-five students answered the pre and post surveys that asked students about their comfort, experience and knowledge of computer skills and Microsoft Office products. Table 1 shows the mean and standard deviation results from administering Survey 1 at the beginning and end of the semester. There were increases in student experience and knowledge in all areas. In addition to showing the percentage increase in the means of the pre and post survey items, a statistical test was used to compare the difference between the pre and post answers using a paired means t-test. The resulting p-values indicate that all items have a mean difference significantly greater than 0 . Hypothesis 1 is supported since all questions showed an increase in the mean from the beginning of the semester to the end.

The results of the second survey pre and post assessments are separated into tables $2 \mathrm{a}$ and $2 \mathrm{~b}$ due to the large number of variable task items that the students were asked to evaluate. Similar to the results of Survey 1, there was a positive increase in the means in all specific Excel task items. The lowest reported increase was $9.2 \%$ and the 


\section{Issues in Information Systems}

Volume 14, Issue 2, pp.298-305, 2013

highest reported increase was $69.7 \%$. All statistical tests comparing the means of pre versus post Survey 2 indicate that the p-value is less than .001 for a two-tailed test of significance. Thus Hypothesis 2 is supported since all questions showed an increase in the mean and the difference in the means for all tasks are greater than 0 .

Table 3 shows the percentage of students who passed the Microsoft Office Specialist exam both on their first and second retake attempt. These results indicate that the proposed model has a positive effect on student learning/engagement through instructional effectiveness.

Table 1. Results of Pre/Post Survey 1 Comparing Computer Skills

\begin{tabular}{|l|c|c|c|c|c|c|}
\hline Question Item & \multicolumn{2}{|c|}{ Beginning of Semester } & \multicolumn{2}{|c|}{ End of Semester } & Percent & $\begin{array}{c}\text { Comparison } \\
\text { of the Means } \\
\text { p-value *** }\end{array}$ \\
\hline Comfort with Computers & 7.09 & 1.81 & 7.85 & 1.46 & $10.7 \%$ & 0.0000 \\
\hline Microsoft Word & 7.90 & 1.45 & 8.49 & 1.29 & $7.5 \%$ & 0.0001 \\
\hline Microsoft Excel & 5.23 & 2.18 & 7.70 & 1.81 & $47.2 \%$ & 0.0000 \\
\hline Microsoft Access & 2.22 & 1.66 & 5.63 & 2.23 & $153.6 \%$ & 0.0000 \\
\hline Microsoft PowerPoint & 6.60 & 1.97 & 8.10 & 1.50 & $22.7 \%$ & 0.0000 \\
\hline Web experience & 7.04 & 1.98 & 8.10 & 1.39 & $15.1 \%$ & 0.0000 \\
\hline Overall IS Concepts & 3.14 & 2.10 & 6.55 & 2.05 & $108.6 \%$ & 0.0000 \\
\hline HTML & 2.79 & 1.93 & 4.59 & 2.54 & $64.5 \%$ & 0.0000 \\
\hline Networks & 3.32 & 2.05 & 5.78 & 2.23 & $74.1 \%$ & 0.0000 \\
\hline
\end{tabular}

$* * * \mathrm{p}<.001$, two-tailed test of significance / paired means test, $n=95$

Table 2a. Pre/Post Survey 2 Results to Assess Specific Excel Tasks

\begin{tabular}{|l|c|c|c|c|c|}
\hline & \multicolumn{2}{|c|}{ PRE EXCEL TEST } & \multicolumn{2}{c|}{ POST EXCEL TEST } & \multirow{2}{*}{$\begin{array}{c}\text { Percent } \\
\text { Task Item }\end{array}$} \\
\cline { 1 - 4 } & Mean & $\begin{array}{c}\text { Standard } \\
\text { Deviation }\end{array}$ & Mean & $\begin{array}{c}\text { Standard } \\
\text { Deviation }\end{array}$ & \\
\hline remove a comment & 9.00 & 1.69 & 9.83 & 0.70 & $9.2 \%$ \\
\hline change margins in excel & 8.25 & 1.98 & 9.79 & 0.72 & $18.7 \%$ \\
\hline hide/unhide rows & 8.19 & 2.11 & 9.76 & 0.73 & $19.2 \%$ \\
\hline create a pivot table & 6.48 & 2.38 & 8.83 & 2.04 & $36.3 \%$ \\
\hline absolute cell reference & 6.72 & 2.59 & 8.57 & 1.84 & $27.5 \%$ \\
\hline relative cell reference & 5.95 & 2.81 & 8.36 & 2.07 & $40.5 \%$ \\
\hline insert an image & 8.58 & 1.89 & 9.76 & 0.76 & $13.8 \%$ \\
\hline modify an image & 7.71 & 2.23 & 9.74 & 0.76 & $26.3 \%$ \\
\hline filter data & 7.60 & 2.38 & 9.48 & 0.96 & $24.7 \%$ \\
\hline insert a chart & 8.89 & 1.35 & 9.72 & 0.74 & $9.3 \%$ \\
\hline modify a chart & 8.21 & 1.88 & 9.64 & 0.79 & $17.4 \%$ \\
\hline define a name range & 6.36 & 2.56 & 9.24 & 1.49 & $45.3 \%$ \\
\hline change print settings & 8.26 & 1.82 & 9.43 & 1.26 & $14.2 \%$ \\
\hline use conditional formatting & 6.96 & 2.38 & 9.33 & 1.39 & $34.1 \%$ \\
\hline use an IF statement & 6.48 & 2.58 & 8.07 & 1.96 & $24.5 \%$ \\
\hline use a COUNTIF statement & 6.31 & 2.52 & 8.12 & 1.96 & $28.7 \%$ \\
\hline
\end{tabular}




\begin{tabular}{|l|l|l|l|l|l|}
\hline insert a sparkline & 7.87 & 2.72 & 9.79 & 0.67 & $24.4 \%$ \\
\hline use concatenate & 3.96 & 2.81 & 6.72 & 2.73 & $69.7 \%$ \\
\hline apply a table style & 8.56 & 1.70 & 9.59 & 1.01 & $12.0 \%$ \\
\hline
\end{tabular}

Table 2b. Pre/Post Survey 2 Results to Assess Specific Excel Tasks

\begin{tabular}{|c|c|c|c|c|c|}
\hline \multirow[b]{2}{*}{ Task Item } & \multicolumn{2}{|c|}{$\begin{array}{c}\text { PRE EXCEL } \\
\text { TEST } \\
\end{array}$} & \multicolumn{2}{|c|}{$\begin{array}{c}\text { POST EXCEL } \\
\text { TEST }\end{array}$} & \multirow{2}{*}{$\begin{array}{l}\text { Percent } \\
\text { Increase }\end{array}$} \\
\hline & Mean & $\begin{array}{l}\text { Standard } \\
\text { Deviation }\end{array}$ & Mean & $\begin{array}{l}\text { Standard } \\
\text { Deviation } \\
\end{array}$ & \\
\hline change cell format & 8.16 & 2.03 & 9.28 & 1.31 & $13.7 \%$ \\
\hline merge and center a cell & 8.99 & 1.74 & 9.84 & 0.62 & $9.5 \%$ \\
\hline change a cell style & 8.08 & 1.97 & 9.52 & 0.88 & $17.8 \%$ \\
\hline create a formula & 8.26 & 1.90 & 9.26 & 1.24 & $12.1 \%$ \\
\hline copy a formula & 8.47 & 1.82 & 9.34 & 1.54 & $10.3 \%$ \\
\hline use goal seek & 6.47 & 2.41 & 7.98 & 2.18 & $23.3 \%$ \\
\hline use the fill handle function & 6.69 & 3.04 & 9.14 & 1.42 & $36.6 \%$ \\
\hline change orientation & 7.08 & 2.72 & 9.45 & 1.30 & $33.5 \%$ \\
\hline group rows and column & 7.31 & 2.48 & 9.05 & 1.36 & $23.8 \%$ \\
\hline create a one variable data table & 6.40 & 2.67 & 8.48 & 1.58 & $32.5 \%$ \\
\hline add a header/footer & 7.92 & 2.14 & 9.72 & 0.74 & $22.7 \%$ \\
\hline add a total row to a table & 8.29 & 2.20 & 9.29 & 1.27 & $12.1 \%$ \\
\hline calculate a percent sales increase & 6.96 & 2.51 & 8.66 & 1.58 & $24.4 \%$ \\
\hline calculate a payment & 6.99 & 2.29 & 8.40 & 1.91 & $20.2 \%$ \\
\hline create a 3-D cell reference & 5.64 & 2.84 & 8.31 & 2.01 & $47.3 \%$ \\
\hline check data validation & 5.82 & 2.84 & 8.78 & 1.59 & $50.9 \%$ \\
\hline compare and merge workbooks & 5.98 & 2.50 & 8.72 & 1.70 & $45.8 \%$ \\
\hline create an average IFS formula & 5.09 & 2.65 & 7.95 & 1.95 & $56.2 \%$ \\
\hline finding and removing elements & 6.45 & 2.73 & 8.95 & 1.62 & $38.8 \%$ \\
\hline use VLOOKUP function & 5.81 & 2.73 & 8.03 & 1.84 & $38.2 \%$ \\
\hline run a what-if analysis from a pivot table & 5.95 & 2.51 & 8.02 & 2.11 & $34.8 \%$ \\
\hline create a pivot chart from a pivot table & 6.01 & 2.73 & 8.40 & 2.12 & $39.8 \%$ \\
\hline sort data & 7.64 & 2.26 & 9.33 & 1.07 & $22.1 \%$ \\
\hline create a hyperlink & 8.46 & 1.87 & 9.71 & 0.79 & $14.8 \%$ \\
\hline save excel workbook into other formats & 8.40 & 2.15 & 9.69 & 0.75 & $15.4 \%$ \\
\hline
\end{tabular}

Table 3. Final MOS Exam Results

\begin{tabular}{|l|c|c|}
\hline & $\begin{array}{c}\text { First } \\
\text { Attempt }\end{array}$ & $\begin{array}{c}\text { Retake } \\
\text { Attempt }\end{array}$ \\
\hline Pass & $84.3 \%$ & $98.6 \%$ \\
\hline Fail & $15.7 \%$ & $1.4 \%$ \\
\hline & $100.0 \%$ & $100.0 \%$ \\
\hline
\end{tabular}




\section{Issues in Information Systems \\ Volume 14, Issue 2, pp.298-305, 2013}

\section{LIMITATIONS AND FUTURE RESEARCH}

The results of this proposed model appear to indicate that using self-efficacy pre and post surveys has a positive effect on student learning. However, there are some limitations. First, this study was conducted for the first time and was not compared to a control group that did not use the proposed model. Secondly, this study was narrowly applied to an introduction to information system course. The pre/post assessment survey only focused on specific items to Excel and was not applied towards any other Microsoft Office application nor any other computing concepts covered in class. Also, this study did not factor out any individual factor differences and treated the entire course as an aggregate. Future research can help to provide validation of the model by replication as well as applying the pre/post assessment survey to other topics. It is also not known how effective this model will be when applied to topics that are not computer-based in nature. Perhaps by applying some of the concepts in the AACSB Assurance of Learning Model can provide some further insight.

\section{CONCLUSIONS}

The issue of determining teaching effectiveness and student performance is complex. From a review of the literature it becomes even more confusing as to whether the current system of student evaluations is the best method for determining instructional effectiveness or student learning. There are too many different issues and potential biases that make it challenging for administrators, faculty, and students to arrive at valid and reliable conclusions. The issues of measuring how much students learn as well as the effectiveness of instructions are too important to leave to doubt. The results of this study seem to indicate that by utilizing a pre/post course and assessment survey and following up with dialogue regarding the reported scores that student engagement and learning can be enhanced and produce positive outcomes which could be attributed to instructor effectiveness

\section{REFERENCES}

1. Aleamoni, L.M.(1999). Student rating myths versus research facts from 1924 to 1998. Journal of Personnel Evaluation in Education, 13(2), 153-166.

2. Arun, R. \& Roska, J.(2011). Academically Adrift: Limited Learning on College Campuses. Chicago, IL: The University of Chicago Press.

3. Arreola, R. A.(1995). Developing a comprehensive faculty evaluation system. Bolton, Mass: Anker.

4. Bandura, A.(1997). Self-efficacy: The exercise of control. New York: Freeman.

5. Berdahl, R.O., Altbach, P.G., \& Gumport, P.J.(2011). American Higher Education in the Twenty-First Century: Social, Political, and Economic Challenges, $3^{\text {rd }}$ Edition. Baltimore: John Hopkins Press.

6. Boex, L.F J. (2000). Attributes of effective economics instructors: An analysis of student evaluations. The Journal of Economic Education, 31(3), 211-227.

7. Braskamp, L. A., Caulley, D., \& Costin, F. (1979). Student ratings and instructor self-rating and their relationship to student achievement. American Educational Research Journal, 16, 295-306.

8. Brown, P. \& Lauder, H.(1996). Education, globalization and economic development. Journal of Education Policy, 11(1), 1-25.

9. Cashin, W. E. (1995). Student ratings of teaching: The research revisited (IDEA Paper No. 32). Manhattan: Center for Faculty Evaluation \& Development, Division of Continuing Education, Kansas State University.

10. Centra, J.A.(1979) Determining faculty effectiveness. San Francisco. Jossey-Bass.

11. Centra, J.A.(1993) Reflective faculty evaluation: enhancing teaching and determining faculty effectiveness. San Francisco: Jossey-Bass.

12. Clayson, D.E. (2009) Student evaluations of teaching: Are they related to what students learn? A metaanalysis and review of the literature. Journal of Marketing Education, 31(1), 16-30.

13. Comm, C. L., \& Manthaisel, D. F. X.(1998). Evaluating teaching effectiveness in America's business schools: Implications for service marketers. Journal of Professional Service Marketing, 16(2), 163-170.

14. Feldman, K. A. (1976). The superior college teacher from the students' view. Research in Higher Education, 5(3), 243-288.

15. Gallaird, F.D., Mitchell, S.P., Kavota, V. (2006). Students, faculty, and administrators' perception of students' evaluations of faculty in higher education business schools. Journal of College Teaching \& Learning, 3(8), 77-90. 


\section{Issues in Information Systems}

Volume 14, Issue 2, pp.298-305, 2013

16. Gomez-Mejia, L.R. \& Balkin, D.B. (1992). Determinants of faculty pay: An agency theory perspective. Academy of Management Journal, 35(5), 921-955.

17. Greenwald, A.G., \& Gillmore, G. M. (1997). No pain, no gain? The importance of measuring course workload in student ratings of instruction. Journal of Educational Psychology, 89, 743-751.

18. Kajitani, A. \& Cohen, D.B.(2010) Fire Teachers, or fix the system? [online], Available: http://www.utsandiego.com/news/2010/Aug/12/fire-teachers-or-fix-system/?\#article-copy).

19. Kulik, J. A.(2001). Student ratings: Validity, utility, and controversy. New Directions for Institutional Research 2001, (109), 9-25.Looney, J. (2011). Developing high-quality teachers: Teacher evaluation for improvement. European Journal of Education, 46(4), 440-455.

20. Liegle, J. O. \& McDonald, D.S. Lessons learned from online vs. paper-based computer information students' evaluation system. In The Proceedings of the Information Systems Education Conference 2004, $21, \S 2214$.

21. Looney, J. (2011). Developing high-quality teachers: Teacher evaluation for improvement. European Journal of Education, 46(4), 440-455.

22. Marsh, H. W. (1987). Students' evaluations of university teaching: Research findings, methodological issues, and directions for future research. International Journal of Educational Research 11(3), 263-388.

23. Marsh, H. W., \& Dunkin, M. (1992). Students' evaluations of university teaching: A multidimensional perspective. In J. C. Smart (Ed.), Higher education: Handbook of theory and research, 8, 143-233. New York: Agathon.

24. Marsh, H. W., \& Roche, L. A. (2000). Effects of grading leniency and low workload on students' evaluations of teaching: Popular myth, bias, validity, or innocent bystanders? Journal of Educational Psychology, 92, 202-228.

25. Miron, M. (1985). The "Good Professor" as perceived by university instructors. Higher Education, 14(2), 211-215.

26. Overall, J.U., \& Marsh, H.W. (1979). Midterm feedback from students: Its relationship to instructional improvement and students' cognitive and affective outcomes. Journal of Educational Psychology, 71(6), 856-865.

27. Pajares, F. (1996). Self-efficacy beliefs in academic settings. Review of Educational Research, 66(4), 543578.

28. Pohlmann, J.T. (1975). A description of teaching effectiveness as measured by student ratings. Journal of Educational Measurement, 12(1), 49-54.

29. Remers, H. H. \& Brandenburg, G. C.(1927). Experimental data on the Purdue Rating Scale for Instruction. Educational Administration and Supervision, 13, 519-527.

30. Schweitzer, C. (2011). Obama Plans to Hit Education Hard in 2011. Neon Tommy USC Annenburg Digital News. Available: http://www.neontommy.com/news/2011/01/obama-plans-hit-education-hard-2011

31. Seldin, P.(1999). Changing practices in evaluating teaching: A practical guide to improving faculty performance and promotion/tenure decisions. Bolton, MA: Anker.

32. Selingo, J. J. (2013). College (un)bound: The future of higher education and what it means for students. New York: Houghton Mifflin Harcourt.

33. Wallace, J.J. and Wallace, WA.(1998). Why the costs of student evaluations have long since exceeded their value. Issues in Accounting Education, 13, 443-447.

34. Wilson, R. (1998). New research casts doubt on value of student evaluations of professors. Chronicle of Higher Education, 44(19), A12-A14.

35. Wode, J. \& Keiser,J. Columbia College Chicago Evaluation \& Assessment Program, Available:http://www.colum.edu/Administrative offices/Academic Affairs/evaluation and assessment/co urseeval/research.php. 